\title{
Mobile Apps, a tool for public health
}

\author{
Las aplicaciones móviles, una herramienta para la salud pública \\ Ma. Elena Cruz-Cortes ${ }^{a}$
}

\begin{abstract}
:
The use of mobile apps in healthcare turned around the paradigm in which the medical service is underneath. M-Health is an increasing sector that offers a lot of innovation possibilities, it makes information available at any time. It allows the access to a large universe of tools that pledge to be of great benefit and become an important resource in the provision of health services due to its easy diffusion, use and wide acceptance. The mobile app help in diagnosis, treatment, disease prevention and effective counseling of health information. The reviewed literature reveal that M-Health in Mexico has a great potential to ameliorate access and quality of health-care services, boosting effectiveness of public health programs and the abatement of health care costs. The objective of this article is to explain the relation and benefits of e-Health and $\mathrm{m}$ - Health in the health care field and to identify the mobile app developed in public and private health care services in Mexico
\end{abstract}

\section{Keywords:}

ICT, e-Health, m-Health, APP

\section{Resumen:}

El uso aplicaciones móviles en salud revoluciona el paradigma bajo el cual se encuentra el servicio médico. M-Health es un sector en crecimiento que of rece muchas posibilidades de innovación, es capaz de facilitar el acceso a la información en todo momento. Permitiendo el acceso a un gran universo de herramientas que prometen ser de gran beneficio y convertirse un recurso importante en la prestación de servicios de salud gracias a su facilidad de difusión, uso y amplia aceptación. Las aplicaciones móviles ayudan en el diagnóstico, tratamiento, prevención de enfermedades y en el manejo efectivo de la información de salud. La literatura revisada revela que las intervenciones de m-Salud en México tienen un gran potencial para mejorar el acceso y la calidad de los servicios de salud, aumentando la efectividad de los programas de salud pública y reduciendo los costos de la atención de salud. El objetivo de este artículo es describir la relación y los beneficios de e-Health y m-Health en el campo de la salud e identificar las aplicaciones móviles desarrolladas en los servicios de salud públicos y privados en México.

\section{Palabras Clave:}

TIC, e-Salud, m-Salud, aplicaciones móviles

\section{INTRODUCTION}

The World Health Organization (WHO) defines health "as a state of physical, mental, and social well-being, and not simply absence of disease or illness."1 In order to meet health needs, human beings from remote times generated new knowledge through the practices learned from generation to generation, which have contributed to scientific and social development. ${ }^{2}$ Information and communication technologies have evolved at an accelerated rate, affecting people's lives, generating transformations in the process of communication and human interaction. ${ }^{3}$ Consequently, the development of medicine in the world was modified, changing the paradigm of socio-sanitary health care. ${ }^{4}$

In this way, it is important to take into account that Information and Communication Technologies (ICT) are defined "as tools and processes to access, to stock, retrieve, organize,

a Corresponding author, Health Services of Hidalgo, Coordination of Health Promotion and Social Participation Sanitary Jurisdiction No.

XII Tizayuca, Hidalgo. México. https://orcid.org/0000-0003-2316-3403. Email: cruzcortesm@ gmail.com 
manipulate, produce, exchange and present information by electronic means". ${ }^{5}$ In this context, ICT's have the attribute of reaching millions of citizens in real time ${ }^{2}$, and their application allows us to move towards informed, equitable, competitive and democratic societies that can also improve care in remote areas and the development of new methods in the health system. $^{6}$

In fact, the use of ICT in health contributes to improving access, costs, effectiveness, efficiency, safety, quality and the generation of knowledge in the field of prevention, diagnosis, treatment, monitoring, education for health and management of health care services in many countries, which are being used to transform the health care system in order to improve access, costs, and quality of health care services. ${ }^{7,8}$ In this sense, the incorporation of ICT in the strengthening of health care systems and integral health in three aspects:

- Management of health care services and access to information; Contributing to the improvement of the operation of health care services. Includes patient registration, administration, human resources, medical equipment, billing and warehouse management.

- Provision of services. In improving the provision of health care services at different levels, it is improved the diagnosis and therapeutic quality, the reliability of the epidemiological mapping and the clinical practice supported by a second opinion among the professionals.

- Information, education and communication. Allows the exchange of knowledge among professionals and the dissemination of health information for the entire population. They can promote a cultural dialogue in alternative health, debate and social mobilization around public health awareness. ${ }^{9}$

With the development of ICT and the introduction of smartphones around the world and their integration into the people's daily lives, the use of mobile technologies by the population has increased ${ }^{10}$; since they are communication tools par excellence, even within the low-income population. ${ }^{11}$

Generating different scenarios in different sectors of society: business (m-business), academia (m-learning), commercial (m -commerce) and social (Facebook, Instagram, Twitter, etc.). ${ }^{11}$ In the field of health, e-Health has emerged and, with technology and mobile devices, it has generated improvements in $\mathrm{m}$-Health that have been introduced in the development of interventions that facilitate the change of healthy behaviors. ${ }^{12}$

The use of smartphones is one of the most promising advances in the field of public health ${ }^{13}$ and in medical practice that has favored the creation of a series of mobile medical and health applications. ${ }^{14,15}$ Therefore, the objective of this article is to describe the relationship and benefits of e-Health and m-Health in the field of health and identify the mobile applications developed in public and private health care services in Mexico.

\section{E-HEALTH}

As a result of the evolution of health and ICT, concepts such as e-Health have been developed in a systematic review, defined and conceptualized "as an interaction and integration of technology in health". ${ }^{16}$ The WHO refers that health consists on "the support that the cost-effective and safe use of information and communication technologies offers to health and related fields, including health care services, health surveillance, and documentation, as well as education, knowled ge and health research". 10,17

E-Health in a health care system is a tool that is used practically at all levels: administration, prevention, diagnosis, treatment and monitoring ${ }^{18}$, from this perspective it is important to review the different components of e-Health:

1. Electronic medical record: it is defined as the electronic format of information on the health of each patient. It helps health care professionals to make informed decisions, increasing safety.

2. Telemedicine: provision of avalanche services using ICT. This makes time and resources more efficient, they improve the quality of life of patients with geographical limitations, reduces waiting times and facilitates the access to health care professionals.

3. m-Health: exercises in medicine and public health as support for mobile devices, patient monitoring devices, and other wireless devices.

4. eLearning: application of ICT to learning, its objective is to increase the access to education and create innovative teaching techniques.

5. Continuous training in ICT: refers to the development of professional health courses or programs that facilitate ICT skills for health.

6. Standardization and interoperability are defined as the communication between different technologies and software applications for the exchange and use of data. It allows the exchange and use of data efficiently and reliably in an integrated way. ${ }^{19}$

E-Health has been established as a useful tool to improve public health, it also increases coverage and universal access to health services, and as a consequence, the attention to patients is strengthened; with the development of communication and interaction platforms in real time., ${ }^{7,20}$ 
In e-Health, there are several components as mentioned above, among them there is m-Health or mobile health. The latter contains the same characteristics and objectives of e-Health, but as a means, it uses mobile devices as a tool to promote health. ${ }^{21}$

\section{M-HEALTH}

The expansion of the uses and functions of mobile technology and the use of the internet has favored the appearance of mobile health or also called m-Health that improves the effectiveness, efficiency and quality of prevention, promotion and health care. ${ }^{21} \mathrm{M}$-Health also facilitates a comprehensive user care, and perhaps the greatest benefit it offers is the autonomy and selfmanagement of their health favoring the development of health interventions. ${ }^{7,13}$

M-Health is defined as the application of telecommunications and other technologies to provide medical assistance and transmit information through mobile devices such as smartphones, laptops, cell consoles, and tablets. ${ }^{7}$ The WHO defines it as the practice of medicine and public health supported by mobile devices, patient monitoring devices, digital personal assistant and other wireless devices. ${ }^{17}$

Globally, m-Health has generated enormous expectations in the transformation of health services, becoming a great ally for health professionals and, at the same time, facilitating the active participation of the population in disease prevention. ${ }^{7,20}$ M-Health offers new opportunities for development in different areas: ${ }^{23}$

a) Communication between people and health services.

b) Communication between health professionals.

c) Health surveillance.

d) Access to information.

WHO refers to the expansion and the impact health has had, as a fundamental axis to guarantee essential and quality health care services, in particular:

- Increase the access to quality health care services; improve the access to health care services through the effective and timely exchange of health data.

- More access to sexual and reproductive health; focusing on improving the quality, coverage, and affordability of valid health interventions.

- Reduce premature mortality and promote changes in the main risk factors for non-communicable diseases, improved diagnosis and monitoring of diseases, personal care, home care and general care for two chronic diseases.
- Increase global health security; obtain information directly for epidemiological surveillance. ${ }^{24}$

M-Health has great potential in the process of the digital transformation of organizations due to its wide variety of apps, for easy use and acceptance; it has become an important resource to provide health care services and develop public health interventions. In this sense, the first appliance in the field of m-Health focused on the use of SMS messages on mobile devices and on alert systems to provide health services. ${ }^{25,26}$

\section{MOBILE DEVICES, THE WAY TO USE AN APP}

Mobile electronic devices are inexpensive, cordless, and portable, with software application support and provide continuous communication from wherever (including text messages, calls, and Internet connectivity), these features make them an important tool for mobile health purposes. ${ }^{7}$

A mobile device is a lightweight device, easy to carry, that has a battery for autonomous operation, such as cell phones, electronic tablets; one of its main characteristics is that they are small, they have processing capacity, wireless mobile network, and a memory, and they are accessible by keyboard or screen. ${ }^{27}$

It is important to mention that in the world there are 5 billion mobile phone users and recent research in Mexico shows that $85.1 \%$ of the population between 18 and 24 years old most likely uses a smartphone, $72.2 \%$ of the population six years old or more uses a telephone and eight out of ten have the possibility to connect to the Internet through a smartphone; while $36.4 \%$ of users download a mobile application (Figure 1).. 28,29

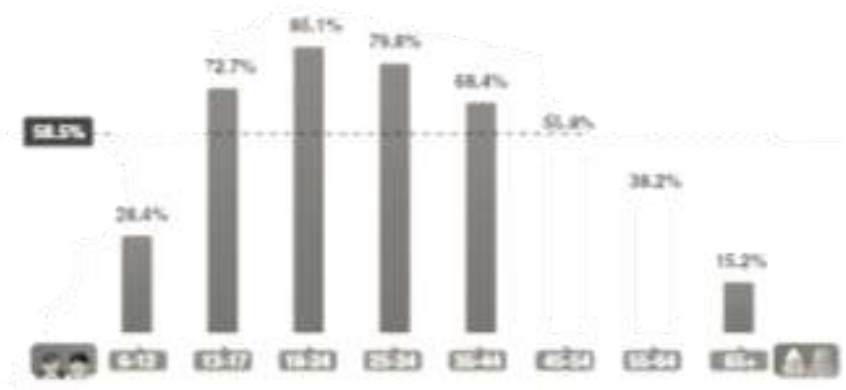

Figure 1. Possibility of use of smartphones pro age groups Source: IFT with data from the 2017 ENDUTIH $^{27}$

Regarding the above, it can be seen that the number of smartphone users has increased, and the download of applications on smartphones has also increased significantly, becoming the main tool to play a key role in the transformation of health care and increase quality and efficiency. ${ }^{30}$ 
This appliance concept also includes applications dedicated to lifestyles or promoting a healthy life. ${ }^{26}$ Therefore, the progress of Information and Communication Technology has a substantial impact on the way in which society and the health care area interact. Since the appearance and normalization of the use of mobile phones, its usefulness has been based on supporting health education programs, from the simple SMS to date, and with the development of specific applications to promote behavior change. ${ }^{31}$

\section{MOBILE APPLICATIONS IN HEALTH, CLASSIFICATION}

The Apps can be classified into categories based on various criteria: in the development environment, business model and functionality. In the first category, focused on the development environment, applications can be native, web or hybrid; in the business model it is subdivided into payment, free and premium; and it is more closely reviewed in the third category of the group's applications for its functionality, that is, according to the type of content offered to the user. In this respect, the latter is subdivided into productive, entertainment, social, educational and informative; in the latter, we can find the health applications. ${ }^{32}$

Currently, there is a classification based on the use of applications, where there is an application aimed at patients and health professionals:

App for patients:

- Self-help tools for chronic diseases (diabetes, hypertension, obesity, etc.)

- Help tools for taking medications.

- Tools to plan the medical consultation.

- Help Tools to improve healthy lifestyles.

- Tools that help to save lives.

App for professionals:

- Training Tools (books, scientific journals, and bibliographic searches).

- Tools to be used in consultation (medical calculators and applications on preventive activities).

- Comprehensive Tools (a combination of different utilities as a reference tool, calculator, health alerts and training). ${ }^{24}$

\section{APP AND ITS APPLICATION IN HEALTH}

It is estimated that $75 \%$ of the world population has access to mobile communication via a mobile device; due to the increased use of these devices a market for mobile applications has emerged. ${ }^{3,24}$ App growth has been extraordinary and is one of the most innovative fields, it is estimated that approximately
700,000 apps are available in different stores for download. In 2018 , in the area of health there were 20,000 apps with 44 million annual downloads. It is estimated that $50 \%$ of the 3.4 trillion mobile devices use health apps. ${ }^{25}$

Mobile apps provide new effective technological tools that have a great impact on health systems around the world. ${ }^{33}$ Mobile applications are popularly called app, which comes from the English term "application". ${ }^{34}$ It is defined as software specifically designed to be downloaded and used on mobile devices or tablets that are distributed by Android and iTunes stores. ${ }^{35,36}$ The main task of an application is to facilitate the achievement of a specific task or help in a specific process. ${ }^{2}$

Currently, two main online apps markets are identified depending on the characteristics of the operating system (OS) installed in the mobile device:

- Google Play (Android), they have published approximately 1.2 million applications, $3.4 \%$ belongs to the category of "Health and Wellness" and $1.8 \%$ in the category "Medicine".

- Apple Store (for iOS devices), there is a total of about 600,000 applications, of which $2.1 \%$ belong to the category of "Health and Wellness" and 2.6\% to "Medicine". ${ }^{26}$

About $70 \%$ of them are those related to physical exercise and weight control, indicated to maintain healthier lifestyles, $30 \%$ focus on any area of health, in its broadest sense, including malaria, HIV-AIDS control of tobacco and alcohol, vaccines, diabetes or pregnancy, and maternity. It is estimated that onethird of the health Apps there will focus on monitoring patients suffering from chronic diseases, active aging or post-acute health care services. ${ }^{37}$

Its use has increased rapidly worldwide, allowing faster transmission of health information because of the mobility of technology and instant access, allowing to place it as a tool in medical practices and public health. ${ }^{38}$ The app is fast, versatile, manageable, and its illustrative use represents a paradigm shift in the field of medicine, as it has become a key tool to empower people for their health. ${ }^{20}$

It is important to keep in mind that in health there is a very heterogeneous group of applications with very different points (diagnosis, monitoring, information, communication, best practices, treatment, prevention or promotion of health) and it is aimed at different types of users (health professionals, chronically ill, acute, specific groups of healthy population among others). ${ }^{5}$

It is also important to highlight that the use of the app democratizes knowledge, that is, users can generate, produce and distribute information. ${ }^{37}$ In fact, there are more patients 
who are informed about a wide range of topics related to health care and who want to use apps in order to have the necessary knowledge for decision-making. ${ }^{20}$ So, apps are becoming an essential change in health around, as an element in different aspects to change the relationships and processes, patient empowerment, changing habits, monitoring and intelligent storage. $^{4}$

\section{THE APP IN PUBLIC HEALTH IN MEXICO}

In Mexico, as in many other countries, applications have been developed based on four main areas: simplification of institutional administration, medical emergency, medical advice and health indicators (including scheduling of events and symptoms) and monitoring of sports cycles or fitness tracking. ${ }^{26}$ Among the applications launched by the public and private health care system were the following in the applications for Android in the Google Play store which are mentioned below (see Table 1$):^{38}$

Table 1. Mobile applications in the public and private health care system in Mexico ${ }^{38}$

\begin{tabular}{|c|c|}
\hline APP & FUNCTION \\
\hline $\begin{array}{l}\text { Name: IMSS DIGITAL } \\
\text { Topic: Health \& Beauty } \\
\text { Downloads: } 100000+\end{array}$ & $\begin{array}{l}\text { It is an application of the Mexican } \\
\text { Social Security Institute that } \\
\text { provides their dependents and } \\
\text { citizens, it is public and free to bring } \\
\text { digital services. Offers access to } \\
\text { the most requested procedures } \\
\text { and services: locating facilities } \\
\text { IMSS, locate clinics for your } \\
\text { location or ZIP code, obtain or } \\
\text { consult your SSN, high and } \\
\text { changing clinic, consult the validity } \\
\text { of rights, schedule medical } \\
\text { appointments for you or your } \\
\text { beneficiaries and health } \\
\text { information. }\end{array}$ \\
\hline $\begin{array}{l}\quad \text { RadarCiSalud } \\
\text { Name: RadarCiSalud } \\
\text { Topic: Health \& Beauty } \\
\text { Downloads: } 10.000+\end{array}$ & $\begin{array}{l}\text { It helps users to know the location } \\
\text { of health facilities and also provides } \\
\text { the best route according to the } \\
\text { transportation. They can also } \\
\text { obtain information from medical } \\
\text { equipment, physical and human } \\
\text { resources of health institutions } \\
\text { nationwide. Another function is to } \\
\text { obtain information on health - } \\
\text { related topics. }\end{array}$ \\
\hline $\begin{array}{l}\text { Name: Seguro Popular } \\
\text { Topic: Health \& Beauty } \\
\text { Downloads: } 10.000+\end{array}$ & $\begin{array}{l}\text { It is an informative application } \\
\text { about the services offered by the } \\
\text { People's Insurance, membership } \\
\text { requirements and re-affiliation, you } \\
\text { can check the validity of your policy } \\
\text { and check module affiliation that } \\
\text { corresponds to the user according } \\
\text { to their address or location. }\end{array}$ \\
\hline
\end{tabular}

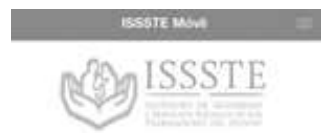

Name: ISSTE Mobile Topic: Health \& Beauty Downloads: $10.000+$

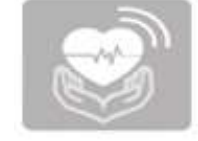

Name: AsISSSTE Infarction Topic: Medicine Downloads: $5000+$

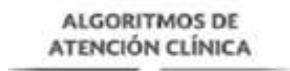

Name: Algorithms Clinical Care

Topic: Health Ministry Downloads: 10 000+

(1)

Name: Digital Health Portfolio

Topic: Health \& Beauty Downloads: $1000+$

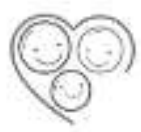

Name: FCS GuiaAPP

Topic: Education Downloads: $1000+$

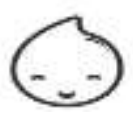

Name: Breastfeeding problem

Topic: Health \& Beauty
This application allows beneficiaries to access to digital ISSSTE services, such as: request or cancel an appointment, locate medical units, kindergartens, cultural centers and shops SUPERISSSTE, access the directory of personnel working in the ISSSTE, enter event publications, newspapers and social networks, print pay stub to pensioners, consultation, simulation and granting personal loans.

An application aimed at ISSSTE beneficiaries and the general public in order to provide support services to the possible presence of myocardial infarction.

This mobile application allows you to see a map that will show the hospital closest to your location, the person may, if it chooses, press the button "Activate Infarction Code" with this action it assigns you the nearest hospital where doctors will be notified and they will be waiting for your immediate attention

Its goal is to have access to information "Algorithms Clinical Care" APP ALGORITHM clinical care is a mobile application that is aimed at health teams and community in general, where it will be allowed to consult each of the stages detection, diagnosis, and treatment of various diseases.

The Digital Health Portfolio offers easy, permanent and timely access to objective information based on the

best evidence. It Includes Clinical Practice Guidelines of the National Health System in Mexico and scientific updates of prestigious national and international drug information and health calculators organizations.

If you are a parent or responsible for children between zero and four years old, this application is foryou.

The experiences that children live during the early years of life will contribute to the formation of their brain, their ability to learn, to acquire skills and how to interact and positively influence their environment. This tool is a proposal based on play activities to promote optimum development.

In this application you will find tips on proper nutrition to improve the quality of the nutrients you eat, your hygiene practices for your baby, breastfeeding products, how to avoid any risk, also discover the common problems that women 


\begin{tabular}{|c|c|}
\hline Downloads: $10,000+$ & $\begin{array}{l}\text { face during this period and learn } \\
\text { how to solve them. } \\
\text { Discover the myths and facts about } \\
\text { breastf eeding }\end{array}$ \\
\hline $\begin{array}{l}\text { Name: GuiaAdultos } \\
\text { Topic: Health \& Beauty } \\
\text { Downloads: } 1000+\end{array}$ & $\begin{array}{l}\text { GuiAdultos app is aimed at people } \\
\text { who need special care as it is the } \\
\text { case of elderly people. } \\
\text { The main functions of the app } \\
\text { include the following: } \\
\text {-Button emergency - notification to } \\
\text { a relative or friend, and } \\
\text { geolocation } \\
\text { - Reminders caretaking } \\
\text { medication and doctor visits } \\
\text { - News - Information related to } \\
\text { health care for the elderly } \\
\text { - Medical Information - Medical } \\
\text { Information Record User }\end{array}$ \\
\hline $\begin{array}{l}\text { Name: Alerta Corazón } \\
\text { Topic: Health \& Beauty } \\
\text { Downloads: } 5000+\end{array}$ & $\begin{array}{l}\text { This app helps anyone who feels } \\
\text { pain; it helps to evaluate the } \\
\text { possibility of suffering a heart } \\
\text { attack and be able to act } \\
\text { immediately. }\end{array}$ \\
\hline $\begin{array}{l}\text { Name: Invasores Chatar } \\
\text { Topic: Health \& Beauty } \\
\text { Downloads: } 1000+\end{array}$ & $\begin{array}{l}\text { Scrap invaders is an exciting game } \\
\text { where you learn about different } \\
\text { diseases such as obesity, diabetes, } \\
\text { and hypertension. }\end{array}$ \\
\hline
\end{tabular}

Therefore, in Mexico, several mobile platforms have been launched to the market aiming at accelerating the administrative processes of institutions and organizations. ${ }^{39}$ The use of mobile technologies can help transforming the provision of health-care services and offers new opportunities for the integration of mobile health apps to health care services. ${ }^{20}$ Within some private areas, new tools and technologies have been developed in order to promote education, training, and knowled ge in health, so people become active elements in their health care attention.

\section{CONCLUSIONS}

E-Health and m-Health, through applications that have reached the field of health to maintain and evolve towards a new model that improves accessibility, allows providing attention at the individual and community levels to encourage and support active and meaningful participation in the management of health over time.

Currently, in Mexico, some applications have been developed that allow us to contemplate projects from different perspectives and generate a broad panorama of the field of application. However, to date, the use and scope of health applications is very limited, so the analysis of contexts must be deepened to identify the most appropriate technologies for the problems posed.

However, more research is needed in these areas to understand their health potential so that they can be the basis and support for innovative state policies, they can be integrated into the health care system, and they can be profitable to improve care and inclusion of the population in the health sector.

\section{REFERENCES}

1. Alcántara Moreno, G. La definición de salud de la Organización Mundial de la Salud y la interdisciplinariedad. SAPIENS. 2008; 9(1): 93107.

2. González JIN, Fernández B. Comunicación, Salud y Tecnología: mHealth. RCyS. 2015; 5(1): 144-53.

3. Spanakis EG, Santana S, Tsiknakis M, Marias K, Sakkalis V, Teixeira A, et al. Technology-Based Innovations to Foster Personalized Healthy Lifestyles and Well-Being: A Targeted Review. J. Med. Internet. Res. 2016; 18(6): e128.

4. Mugarza F. Informe de las mejores 50 apps de salud en español. App Intell [Document on the de internet]. 2014. [updated 2018 december 10, 2018; cited 2019 February 25]. Available from: http://boletines.prisadigital.com/Informe-TAD-50-Mejores-Apps-deSalud.pdf

5. Loyola MS. Las tecnologías de la información y la comunicación (TIC) en educación en América Latina: una política educativa. CULCyT. 2014; 52(11): 85-92.

6. Ortiz-Chacha CS, Blázquez-Morales MSL, García-González J, DuarteGómez MB, De-San-Jorge-Cárdenas XMC, Méndez-Main SM. Tecnologías de la información y comunicación para el cuidado y atención del embarazo en el primer nivel de atención. Ciencia UAT. 2018; 12(2): 40-53.

7. Ruiz EF, Proaño A, Ponce OJ, Curioso WH. Tecnologías móviles para la salud pública en el Perú: lecciones aprendidas. Rev.Perú Med. Exp. Sal. 2015; 32(2): 364-72.

8. Fitzgerald M, McClelland T. What makes a mobile app successful in supporting health behaviour change? Health Educ. J. 2017 ; 76 (3): 373-81.

9. Bebea I. (2014). TIC y Salud.Cuadernos TIC para eldesarrollo humano. ONGAWA, $6, \quad 22 . \quad$ Available from: http://www.codajic.org/sites/www.codajic.org/files/TIC y salud.pdf

10. OMS, OPS. Estrategia y Plan de Acción sobre eSalud. [Document on the de internet].2011. [update 2019 february 23; cite 2019 February 23] Available from: https://www.paho.org/hq/dmdocuments/2011/CD51-13s.pdf

11. Mantilla MC, Camargo-Ariza LL, Medina-Delgado B. Metodología para el desarrollo de aplica ciones móviles. TECNURA. 2014; 18 (40): 2035.

12. Lewis J, Ray P, Liaw ST. Recent Worldwide Developments in eHealth and mHealth to more Effectively Manage Cancer and other Chronic Diseases - A Systematic Review. Yearb. Med. Inform. 2016; 10 (1): 93108.

13. Frenk J. La salud móvil y los sistemas de salud: Determinantes del progreso en la salud global. Rev. Perú Med. Exp. Salud Pública. 2015;32 (2):361-3.

14. Brian RM, Ben-Zeev D. Mobile health (mHealth) for mentalhealth in Asia: Objectives, strategies, and limitations. Asian J. Psychiatr. 2014;10: 96-100.

15. Nograro SC. Potencialidad de uso de las aplicaciones móviles de salud en un grupo de población española. RqR. Enfermería Comunitaria. 2015; $3(3): 42-53$. 
16. Ordúz R. Tecnologías de la información: uso en el sector salud. Ordúz R. Vallejo E, editors. Las TIC en algunos de los retos del sector salud: panorama, experiencias y perspectivas. 7 th ed. Colombia: Colombia Digital; 2013;1-60.

17. Velasco-Rodríguez G. Mercadotecnia social: las aplicaciones móviles en el mercado sanitario. Horiz. Sanitario. 2018; 17(1): 9-20.

18. Mariscal J, Gil-García JR, Ramírez-Hernández F. e-Salud en México: antecedentes, objetivos, logros y retos. Esp. Púb. 2012;15(34):65-94.

19. Organización Mundial de la Salud. Constitución de la Organización Mundial de la Salud. [Document on the de internet].2006. [update 2018 november 13; cite 2019 Febrary 24]. Available from: https://www.who.int/governance/eb/who_constitution_sp.pdf

20. Novillo-Ortiz D. Sanidad móvil (mSalud) In: Organización Panamericana de la Salud, editors. La eSalud en la Región de las Américas: derribando las barreras a la implementación. Resultados de la Tercera Encuesta Global de eSalud de la Organización Mundial de la Salud. 1st. Ed. Washington, DC: OPS; 2016:68-83.

21. Brunette MJ, Curioso WH. Sistemas de salud móvil integrados: rol de los factores socioculturales y el enfoque de sistemas sociotécnico. Rev. Perú Med. Exp. Salud Pública. 2017; 34(3):544-50.

22. Ryu, S., Book review: mHealth: New horizons for health through mobile technologies: Based on the findings of the second global survey on eHealth (globalobservatory for eHealth series, volume 3). Healthc. Inform. Res. 18(3):231.

23. Carnicero J, Rojas D, Blanco O. La gestión de la función TIC en los servicios de salud: algunos errores frecuentes de los equipos de dirección. In: Abad A, Amézqueta C, Blanco O, Carnicero J, Curioso W, et. al., editors. Manualde salud electrónica para directivos de servicios y sistemas de salud. 2nd ed. Santia go CEPAL 2014;55-78.

24. García H, Navarro L, López M, Rodríguez MF. Tecnologías de la Información y la Comunicación en salud y educación médica. Rev. EduMeCentro. 2019; 6(1):253-65.

25. Santamaría-Puerto G, Hernández-Rincón E. Aplicaciones Médicas Móviles: definiciones, beneficios y riesgos. Salud Uninorte. 2016;31(3): 599-607.

26. Sa lido J, Suárez OD, Bueno G. Desarrollo de aplicaciones de sa lud para dispositivos móviles. I + S: Informática y salud, 2015;100: 8-13.

27. Instituto Nacionalde Esta dística y Geografía. Encuesta Nacional sobre Disponibilidad y Uso de las Tecnologías de la Informa ción en los Hogares (ENDUTIH). [Document on the de internet]. 2014. [update 2019 February 13; cited 2019 February 13,]. Available from: http://www.beta.inegi.org.mx/proyectos/enchogares/regulares/dutih/2017/ default.html

28. Park E, Kwon M. Health-related internet use by children and adolescents: Systematic review. J. Med. Internet Res. 2018;20 (4): e120.

29. Instituto Federal de Telecomunicaciones (IFT). Uso de las tic y actividades por internet en [Document in Internet]. 2018 [update 2019 february 10; cited 2019 February 12]. Available from: http://www.ift.org.mx/sites/default/files/contenidogeneral/estadistica s/ado pciondelasticyusosdeinternetenmexico.pdf

30. Eleuteri S, Rossi R, Tripodi F, Fabrizi A, Simonelli C. Sexual health in your hands: How the smartphone apps can improve your sexual wellbeing? Eur. J. Sex. Health. 2018; 27(3): 57-60.

31. Jones EC, Storksdieck M, Rangel M. How Social Networks May Influence Cancer Patients' Situated Identity and Illness-Related Behaviors. Front. Public. Health. 2018; 6: 240.

32. Ávila JF. Aplicaciones para terminales móviles en salud. FMC, Form. Méd Contin. Aten. Prim.2012; 19(10):613-20.

33. López-Satín JM, Álvaro P. La salud mentaldigital. Una aproximación crítica desde la ética. Rev. Asoc. Esp. Neuropsiquiatr. 2018;38(134): 35979.
34. Grau I, Kostov B, Gallego JA, Grajales F, Fernández-Luque L, SisóAlmirall A. Método de valoración de aplicaciones móviles de salud en español: el índice iSYScore. SEMERGEN, Soc. Esp. Med. Rural Gen. 2016; 42(8):575-83.

35. Elias BL, Fogger SA, McGuinness TM, D'Alessandro KR. Mobile Apps for Psychiatric Nurses. J. Psychosoc. Nurs. Ment. Health Serv. 2014; $52(4): 42-7$.

36. Santamaria G, Hernández E. Aplicaciones Médicas Móviles definiciones, beneficios y riesgos. Salud Uninorte. 2015;31(3):599-607.

37. Fernández-Sa lazarS, Ramos-Morcillo AJ. Nuevas tecnologías, apps y su aplicación en la práctica clínica basada en evidencias. Enferm. Clin. 2014;24(2):99-101.

38. Android apps on Google Play. [Document on the de internet]. 2019 [update 2019 march 1 ; cited 2019 march 6]. Health \& Wellness. Available from: https://play.google.com/store/apps

39. Espinoza-Bautista JR, Álvarez-Ballesteros S, Romero-Castro M. mHealth indispensable para la salud de los mexicanos. Científica 2017; 21(1):25-34 